\title{
POST-BASIC NURSING STUDENTS' PERCEPTIONS OF THE EMIGRATION OF NURSES FROM THE REPUBLIC OF SOUTH AFRICA
}

\section{Dr VJ Ehlers}

B Soc Sc, Hons B Soc Sc (Psychology), BA Cur, Hons BA Cur, MA Cur, D Litt et Phil, Diploma in Development Studies

Department of Health Studies, University of South Africa

Corresponding author: ehlervj@unisa.ac.za

\section{Mrs MJ Oosthuizen}

B Cur, BA Cur, Hons BA Cur, MA Cur

Department of Health Studies, University of South Africa

\section{Dr MC Bezuidenhout}

BA Cur, M Cur, D Litt et Phil

Department of Health Studies, University of South Africa

\section{Mrs LV Monareng}

BA Cur, Hons BA Cur, MA Cur, M Sc

Department of Health Studies, University of South Africa

\section{Prof K Jooste}

BA Cur, Hons BA Cur, MA Cur, D Litt et Phil

Department of Nursing Science, Rand Afrikaans University

Key phrases: emigration of South African nurses; migration of nurses; nursing shortage in the RSA

\begin{abstract}
The emigration of nurses from South Africa to work in overseas countries continues to increase despite efforts to curb this phenomenon. This exploratory descriptive survey attempted to identify nurses' perceptions of their colleagues who have emigrated as well as their own intentions to emigrate should the opportunity arise. Selfcompletion questionnaires were posted to all students registered for under- and postgraduate studies at a distance education institution. The analysis of the data obtained from 453 completed questionnaires indicated that almost all respondents knew nurses who had emigrated, and that approximately $60 \%$ of the respondents would emigrate if the opportunity should arise. The major deterrent to their emigration was family ties which kept them in South Africa. The major reasons why they would emigrate related to better remuneration and to the ability to save money quickly for specific reasons. Besides improved remuneration and fringe benefits, employers could help nurses to remain in the Republic of South Africa (RSA) by showing appreciation for their work, by improving facilities and resources and by appointing competent health managers. The South African government could help nurses to remain within the RSA by appointing people in the frozen posts, eliminating corruption within the government and by improving safety and security in the country. Almost all respondents indicated that the government had no right to prevent South African nurses from emigrating to other countries.
\end{abstract}

\section{OPSOMMING}

Die emigrasie van Suid-Afrikaanse verpleegkundiges om in oorsese lande te werk neem toe ten spyte van pogings om die verskynsel te bekamp. ' $n$ Verkennende, beskrywende opname is gedoen ten einde verpleegkundiges se persepsies te verken oor kollegas wat geëmigreer het asook hulle eie voornemens om te 
emigreer indien die geleentheid sou voorkom. Vraelyste wat die studente self moes voltooi is aan alle studente gepos wat vir voor- of nagraadse studies by ' $n$ afstandsonderriginstelling geregistreer was. Die ontleding van die data wat verkry is vanaf die 453 voltooide vraelyste het aangedui dat bykans alle respondente verpleegkundiges geken het wat reeds geëmigreer het, en dat ongeveer $60 \%$ van die respondente sou emigreer indien hulle so 'n geleentheid sou kry. Die belangrikste faktor wat hulle emigrasie teengewerk het was familiebande wat hulle in Suid-Afrika gehou het. Die hoofredes waarom hulle sou emigreer het verband gehou met beter besoldiging en met die vermoë om vinnig geld te spaar vir spesifieke doeleindes. Benewens verbeterde besoldiging en byvoordele kan werkgewers verpleegkundiges help om in RSA te bly deur waardering te toon vir hul werk, deur fasiliteite en bronne te verbeter en deur bevoegde gesondheidsorgbestuurders aan te stel. Die Suid-Afrikaanse regering kan verpleegkundiges help om in die RSA aan te bly deur mense in bevrore poste aan te stel, korrupsie binne die regering uit te roei en die veiligheid en sekuriteit in die land te verbeter. Bykans alle respondente het aangetoon dat die regering nie oor die reg beskik om Suid-Afrikaanse verpleegkundiges te verbied om na ander lande te emigreer nie.

\section{INTRODUCTION AND BACKGROUND IN- FORMATION}

Migration can be defined as movement from one place to another (Oxford Handy Dictionary, 1991:552). In the context of this article 'migration' refers to the movement of nurses from one country to another. Migration comprises two parts: emigration implying the movement out of a specific country and immigration denoting movement into a specific country. Thus the emigration of nurses from the Republic of South Africa (RSA) refers to the movement of nurses out of the RSA to practise their profession in other countries.

The Director-General of the World Health Organization stated that: "Nursing and midwifery services are a vital resource for attaining health and development targets. ... Migration of health workers... constrains the provision of needed services. Failure to solve these problems will have serious implications for the quality and coverage of health care" (Brundtland in WHO, 2002:vi).

During 1999, an estimated 3300 professional nurses emigrated from the RSA and 200 professional nurses approached the South African Nursing Council (SANC) for overseas registration on a monthly basis (DENOSA, 2001:10). The emigration of large numbers of nurses from the RSA impact negatively on the provision of health services throughout the country, but more so in the rural areas where nurses might be the only professional health care providers. In an attempt to address the shortage of medical practitioners in the RSA, foreign doctors, from countries such as Cuba and Poland, have been recruited to work in public health care settings. Nurses play a major role as interpreters between patients who do not speak English and doctors who do not understand their patients' languages nor their cultural concepts of health and illness.

The direct results of a shortage of professional nurses include the closure of hospital wards and/or clinics, reducing the available health care services; leading to long waiting lists at health care facilities. The major indirect result of such shortages revolves around the increased workloads experienced by the remaining nurses. Those professional nurses who can leave, do so, further aggravating the situation for those remaining in the RSA. "In South Africa, hospitals are struggling with the exodus of nurses to richer countries ... leaving the country with a shortage of 20000 qualified staff" (Ka Mzolo, 2001:38). The number of student nurses following the four-year comprehensive (R425) programme declined from 11903 in 1997 to 9639 in 2001 (DENOSA, 2001:6).

The global shortage of nurses is aggravated by the fact that large numbers of nurses globally fall within the age range of the "baby boomers" born between 1946 and 1952; implying that these nurses will reach retirement ages between 2005 and 2020. The United Kingdom's (UK's) shortage of nurses has been predicted to reach 57000 by 2004 (Ka Mzolo, 2001:38). In the United States of America (USA) the shortage of nurses is predicted to be 291000 in 2020, but the USA shortage will be hard hit by the expected retirement of $50 \%$ of the USA's nurse lecturers by 2010 (Purnell, Horner, Gonzalez \& Westman, 
2001:179). South African nurses, whose training as well as their ability to communicate in English are valued by many countries, could help to address the dire shortage of nurses in the English speaking countries, while enhancing their own standard of living (Christmas, 2002:20). The emigration of nurses from the RSA is unlikely to decrease while numerous advertisements lure these nurses to work in other countries. One advertisement in the December/January 2003 issue of Nursing Update (unnumbered pages) offered nurses from the RSA 15000 nursing positions throughout the USA; as well as large numbers of posts in the UK, Saudi Arabia and Australia.

The research problem can be stated as: The RSA has a shortage of registered nurses which is aggravated by the continued emigration of South African nurses to work in foreign countries. The purpose of the research was to:

- identify perceptions influencing nurses to emigrate from the RSA;

- identify factors which would influence them to stay in the RSA; and

- determine whether or not the South African government could prevent nurses' emigration from the RSA.

The research questions comprised identifying

a) reasons why:

- nurses known to the respondents emigrated from the RSA

- the respondents themselves considered emigration

- they did or did not emigrate

b) ways in which nurses could be assisted to remain in the RSA by

- employers

- the South African Government and

c) whether or not the South African Government could prevent nurses' emigration from the RSA to work in foreign countries.

\section{RESEARCH DESIGN}

In this section the methodology, population and research instrument will be discussed. Issues pertaining to reliability, validity and ethical aspects will also be addressed.

\section{Methodology}

A quantitative, exploratory and descriptive design was used to ascertain the reasons why nurses left South Africa to work abroad. Postal questionnaires were used to collect data for this survey.

\section{Population}

The population comprised 4280 students registered at a tertiary, distance education institution for underor postgraduate nursing studies during 2000. A census was done as each student was requested to participate in the survey.

\section{Research instrument}

A structured questionnaire was used to collect data from nurses pertaining to reasons as to why their colleagues and/or themselves, emigrated or considered emigrating, or would (in future) consider emigrating from South Africa to work in other countries.

Open- and closed-ended questions were accommodated in the questionnaire which contained 264 items. Open-ended questions allowed the subjects to respond in their own words whereas closed-ended (or fixed alternative) questions offered respondents a number of possible replies from which they had to choose the most appropriate alternatives according to their views.

The questionnaire consisted of the following sections:

- biographic information of the respondents, including gender, age, race, marital status, number of children, and employment sector (public versus private)

- knowledge of nurses who left the RSA

- knowledge about nurses currently considering leaving the RSA

- respondents who have left the RSA and are currently working in overseas countries

- current considerations of respondents to emigrate from the RSA and to go and work elsewhere in the world

- previous considerations to emigrate from the RSA and to work elsewhere in the world, and reasons for not leaving the RSA 
- intention to leave the RSA should the opportunity arise; including reasons for not intending to leave the RSA and reasons for wanting to emigrate from the RSA

- aspects which might make nurses stay in the RSA; including what employers can do to keep nurses in the RSA, and what the South African government can do to keep nurses in the RSA

- nurses' perceptions as to whether the South African Government could prevent them from finding employment in other countries.

\section{Validity and reliability}

Content validity of an instrument is the extent to which the instrument represents the factors under study. Each content area must be defined and representative behaviours then identified (Dempsey \& Dempsey, 1992:75). Face validity is a subtype of content validity and is determined by inspecting the items in the questionnaire to ascertain whether the instrument contains important items that measure the variables in the content area (Burns \& Grove, 1993:343-4).

The content of the questionnaire was developed by the research team, making use of information gained from the literature, radio news, newspaper articles and television programmes. Content and face validity were ensured by submitting the questionnaire to a number of experienced research academics and professional nurses. These experts agreed that the instrument complied with face and content validity.

Reliability of an instrument can be equated with the stability, consistency or dependability of a measuring tool (Nieswiadomy, 1993:201). The degree of reliability is usually determined by the use of correlation procedures. A correlation coefficient is determined between two sets of scores or between the ratings of two judges and is expressed as a number. Correlation coefficients range between $-1,00$ and +1.00 . If the scores are perfectly correlated, the correlation coefficient is 1,00 (Polit \& Hungler, 1993:244-245). Although no specific correlation coefficients were statistically calculated for determining the reliability of this research instrument, the statisticians were satisfied that expected correlations between related findings were found.

\section{Data collection and analysis}

Questionnaires were posted to 4280 registered students studying at a distance education tertiary institution requesting them to participate in this project. An accompanying letter indicated that all information would be treated confidentially and that they would remain anonymous. Of the 4280 questionnaires, 453 were returned, representing a response rate of 10.58 percent. Although this response rate was disappointing low, no follow-up procedures were pursued as no distinctions could be made between those students who submitted completed questionnaires and those who failed to do so. Resending another 4280 questionnaires and/or follow-up letters would have been too expensive. An analysis of the data contained in the 453 returned questionnaires could provide exploratory descriptive quantitative data about reasons why nurses emigrated from South Africa, or considered emigrating. Although the data obtained from such a small percentage of potential respondents might be inadequate to use for policy formulations, it could provide worthwhile information for future research.

The data was quantitatively analysed, using the Statistical Package for Social Sciences (SPSS) computer programme.

\section{Ethical considerations}

Participants received the questionnaires with a cover letter stating that their anonymity was ensured. Students who did not complete questionnaires could not be discriminated against nor intimidated in any way, because there was no way to determine which students returned completed questionnaires and which students failed to do so. Participation was voluntary. As anonymity had to be maintained, it was accepted that those students who returned completed questionnaires, consented to doing so. This research was approved by the Departmental Research and Ethics Committee of the particular educational institution.

\section{RESEARCH RESULTS}

The discussion of the research results refers to the data obtained from the $453(\mathrm{~N}=453)$ completed ques- 
tionnaires. However, as these were self-completion questionnaires, a number of questions were left unanswered, accounting for the reason that the total number of responses do not add up to 453 in each case. In accordance with the data produced by the SPSS programme, the number of non-responses are indicated in the tables. Furthermore, in terms of the statistics produced by the SPSS programme, the cumulative frequencies add up to approximately $100 \%$ in some cases - depending on the calculations of the percentage for each category - but these statistics are portrayed as produced by the SPSS programme by two statisticians from Unisa's Department of Computer Services. This implies that the statistics were not changed to produce a cumulative percentage of exactly $100 \%$, but are reported as produced by the SPSS programme.

\section{Introduction}

The research results will be presented and discussed according to the different sections of the questionnaire.

\section{Biographic information of the respondents}

The biographic data of the respondents provide important information about who these respondents were in order to contextualise their knowledge and perceptions about the emigration of nurses from the RSA, as well as their own intentions and/or abilities to emigrate. As the nursing profession in the RSA is predominantly a female profession, the gender constitution of the 453 respondents (428 or $94.5 \%$ females versus 23 or $5.1 \%$ males and 2 or $0.4 \%$ nonresponses) was to be expected.

Table 1 indicates that the majority of the respondents (348 or $76.8 \%$ ) fell within the age groups ranging from 31 to 50 years of age. This finding was to be expected in terms of the target population, namely registered nurses pursuing post-basic programmes with a distance education institution.

As $52.1 \%$ of the respondents' ages did not exceed 40 and $89.7 \%$ did not exceed 50 years of age, it could be assumed that these respondents might provide useful information pertaining to the emigration of nurses from the RSA, as most nurses who emigrate would need to be younger than 50 , if not 40 , to obtain work permits in foreign countries and to make the emigration process worth their while.

The majority (314 or $69.3 \%$ ) of the respondents were Black, 18.3\% White, 7.3\% Coloured and 4.6\% Asian with $0.4 \%$ non-response.

Table 1: Age distribution of respondents $(n=453)$

\begin{tabular}{|l|l|l|l|}
\hline Age group & $n$ & $\%$ & Cumulative \% \\
\hline 30 or younger & 58 & 12.8 & 12.8 \\
\hline $31-40$ & 178 & 39.3 & 52.1 \\
\hline $41-50$ & 170 & 37.5 & 89.6 \\
\hline 51 or older & 45 & 9.9 & 99.7 \\
\hline TOTAL & & & \\
\hline Non-response & 2 & 0.4 & \\
\hline TOTAL & 453 & 99.9 & \\
\hline
\end{tabular}


Out of the 450 respondents who indicated their marital status, more than half (268 or $59.2 \%$ ) were married; and approximately one third (141 or $31.1 \%$ ) indicated their marital status as being "single", while $28(6.2 \%)$ were divorced and 13 (2.9\%) were widowed. (There were only 3 or $0.7 \%$ non-respondents to this question). It might be presumed that the $40.2 \%$ who were not married $(31.1 \%$ single, $6.2 \%$ divorced and $2.9 \%$ widowed) might be more likely to seek emigration opportunities than those with marital ties. The decision to emigrate or not might also be significantly influenced by each respondent's children.

The majority (364 or $80.4 \%$ ) of the respondents indicated that they had children while $87(19.2 \%)$ had no children. Based on this finding, it could be assumed that the respondents' children might influence them not to emigrate from the RSA.

Approximately two-thirds (302 or $67.1 \%$ ) of the respondents were employed in the public sector, with $110(24.3 \%)$ in the private and $35(7.7 \%)$ in other (unspecified) sectors. (Four persons or $0.9 \%$ failed to respond to this question).

\section{Knowledge of nurses who emigrated or who intended to emigrate from the RSA}

Surprisingly $94.0 \%$ (426) respondents knew registered nurses who had left the RSA. Even more surprising was the answer that $60.0 \%$ (272) knew more than five nurses who had actually done so, and $96.5 \%$ (437) thought they knew why these nurses had left the RSA. The respondents indicated that the nurses known to them who emigrated from the RSA practised in the following fields: general nursing, intensive care units, theatre, paediatric units, midwifery units, psychiatric units and geriatric units. These answers indicate that nurses working in almost any health care field managed to emigrate from South Africa. As many as $90.1 \%$ (408) respondents knew about nurses who were considering leaving the RSA to work in other countries.

Based on the data reflected in Table 2, it can be deduced that the major reasons why nurses left the RSA corresponded with the major reasons why they were considering leaving the RSA.
The two most important reasons were to find better remuneration ( $84.0 \%$ and $77.5 \%$ ) and to save money quickly for a specific purpose $(79.7 \%$ and $72.7 \%)$. Both these reasons indicated that nurses perceived their salaries to be poorer in the RSA than those offered in other countries.

The possibility of earning better salaries overseas than in the RSA is indeed illustrated by advertisements in the December 2002/January 2003 issue of Nursing Update, the official professional journal for nurses published by DENOSA. In this issue there was an advertisement for professional nurses within the RSA (Mpumalanga Province) offering a salary of R64 600.00 per annum while posts in Saudi Arabia were advertised offering salaries from R22 000.00 to R35 000.00 per month, or from R264 000.00 to R420 000.00 per annum - 6.5 times more than the advertised RSA salaries (Nursing Update, 2002/ 2003:advertisements: unnumbered pages). Salaries advertised in the UK ranged from R240 000.00 to R375 000.00 per annum. In this same issue of Nursing Update posts are advertised for nurses, not only in Saudi Arabia and the UK but also in Australia, the USA, Ireland, United Arab Emirates, Oman, Dubai, Abu Dabi, New Zealand and the Netherlands. In some countries tax free earnings, free airfares, free medical aid, free accommodation and/or end of contract bonuses are advertised, enabling South African nurses to earn up to ten times more overseas than they could in the RSA.

\section{Respondents who were actually working in countries other than the RSA}

Although all the respondents were registered underor postgraduate distance education students, 30 $(6.6 \%)$ indicated that they were indeed working in other countries at the time of completing the questionnaires during 2001. Numerous reasons were provided for having left the RSA to work abroad, but the three major reasons were: the challenge of going to a new country $(58.6 \%)$; to save money quickly (58.6\%) and the workload in the South African health services was too heavy $(51.7 \%)$.

It is interesting to note that the reasons for actually working in foreign countries were reportedly somewhat different from those perceived by nurses still living and 
Table 2: Reasons other nurses known to respondents (a) have left the RSA or (b) are considering leaving the RSA

\begin{tabular}{|l|l|l|l|l|}
\hline $\begin{array}{l}\text { Reasons known to respondents why other } \\
\text { nurses (A) have left the RSA or (B) are } \\
\text { considering leaving the RSA }\end{array}$ & $\mathrm{A}(\mathrm{f})$ & $\mathrm{A}(\%)$ & $\mathrm{B}(\mathrm{f})$ & $\mathrm{B}(\%)$ \\
\hline Found better remuneration abroad & 368 & 84.0 & 321 & 77.5 \\
\hline Want to save money quickly for a purpose & 349 & 79.7 & 301 & 72.7 \\
\hline To have better living conditions & 245 & 55.9 & 233 & 56.3 \\
\hline Workload in the RSA too heavy & 225 & 51.4 & 193 & 46.6 \\
\hline Decline of general economic situation in RSA & 199 & 45.4 & 171 & 41.3 \\
\hline Insufficient opportunities for promotion in RSA & 195 & 44.5 & 172 & 41.5 \\
\hline There is no future in RSA & 186 & 42.5 & 153 & 37.0 \\
\hline $\begin{array}{l}\text { Lack of resources/facilities within RSA health } \\
\text { care system }\end{array}$ & 180 & 41.1 & 143 & 34.5 \\
\hline General decline of public services in RSA & 168 & 38.4 & 163 & 39.4 \\
\hline Poor management of health services in RSA & 158 & 36.1 & 150 & 36.2 \\
\hline To gain experience abroad & 153 & 34.9 & 120 & 29.0 \\
\hline High levels of crime and violence in the RSA & 142 & 32.4 & 131 & 31.6 \\
\hline To ensure a safe haven for their children & 136 & 31.1 & 114 & 27.5 \\
\hline Saw challenges in a new country & 103 & 23.5 & & \\
\hline Deterioration of value system in RSA & 100 & 22.8 & 98 & 23.7 \\
\hline To travel and see the world & 87 & 19.9 & 71 & 17.1 \\
\hline General sense of despondency in RSA & 83 & 18.9 & 78 & 18.8 \\
\hline Unacceptable work tempo in RSA & 73 & 16.7 & 77 & 8.6 \\
\hline Dissatisfied with SA public schools & 53 & 12.1 & 46 & 11.1 \\
\hline Family related reasons & 38 & 8.7 & 38 & 9.2 \\
\hline To join family/friends abroad & 28 & 6.4 & 30 & 7.2 \\
\hline Could not find a job in SA & & & 29 & 7.0 \\
\hline
\end{tabular}

working in the RSA. However, as the number of respondents who actually lived and worked in foreign countries was extremely small (30 or $6.6 \%$ of the respondents), more research would need to be conducted among nurses who are actually working abroad prior to making any conclusions about this group of South African nurses.

\section{Respondents' intentions to work in coun- tries other than the RSA}

Respondents were asked three questions related to their intentions to work in countries other than the RSA. These responses are summarised in Table 3.

The results portrayed in Table 3 indicate that more than half of the respondents had previously, were at the time of completing the questionnaires, and would in future consider leaving the RSA to work in other countries. The fact that $59.8 \%$ of the respondents would leave the RSA should the opportunity arise, needs to be viewed seriously by the RSA's health care planners, 
Table 3: Respondents' intentions to leave the RSA

\begin{tabular}{|l|l|l|}
\hline Respondents' intentions to leave the RSA & $\mathbf{n}$ & $\%$ \\
\hline Currently considering leaving the RSA to nurse elsewhere & 264 & 58.3 \\
\hline Considered leaving the RSA to nurse elsewhere in the past & 255 & 56.3 \\
\hline Would leave the RSA, if provided the opportunity & 271 & 59.8 \\
\hline
\end{tabular}

as opportunities seem to increase continuously for South African nurses to work in foreign countries. The health services generally, and the nursing services in particular, could collapse if almost $60 \%$ of the RSA's nurses should leave the country.

\section{Reasons why respondents considered leaving the RSA}

Respondents were asked why they considered leaving the RSA at some earlier stages of their lives, why they did so at the time of completing the questionnaire (indicated in Table 4 as "current") or why they would leave the RSA in future should the opportunity arise. Only reasons marked by more than $40 \%$ of the respondents are reflected in Table 4.
Further analysis of the data, using specific functions of the SPSS program indicated the following interesting differences for reasons considering to leave the RSA according to employment sector:

- for better remuneration (74.6\% public; $68.2 \%$ private; $65.0 \%$ other sector)

- to quickly save money $(75.1 \%$ public; $45.5 \%$ private and $55.0 \%$ other sector).

Surprisingly the majority of nurses aged between 41 and 50 considered emigration from the RSA to get better salaries $(76.5 \%)$ and to save money quickly (69.4\%). Nurses aged between 41 and 50 could be regarded as being in their peak performance years. Losing their knowledge and expertise could impact negatively on the services to be rendered by the younger

Table 4: Respondents' previous, current and future intentions to work in countries other than the RSA ( $\mathrm{n}$ given for each column in Table 4)

\begin{tabular}{|l|l|l|l|}
\hline Reasons for considering leaving the RSA & $\begin{array}{l}\text { Current } \\
\%: \mathrm{n}=353\end{array}$ & $\begin{array}{l}\text { Previous } \\
\%: \mathrm{n}=268\end{array}$ & $\begin{array}{l}\text { Future } \\
\%: \mathrm{n}=297\end{array}$ \\
\hline Better remuneration abroad & 71.3 & 65.4 & 67.3 \\
\hline To quickly save money & 65.7 & 61.2 & 60.9 \\
\hline To have better living conditions & 54.5 & 48.8 & 54.9 \\
\hline Workload in SA health services too heavy & 47.8 & 36.2 & 42.4 \\
\hline To gain experience abroad & 47.4 & 43.8 & 51.9 \\
\hline Insufficient opportunities for promotion & 47.0 & 40.8 & 42.1 \\
\hline Poor management of health services in SA & 43.7 & 33.8 & 46.8 \\
\hline General decline of public services in SA & 43.3 & 38.5 & 41.8 \\
\hline New challenges in a new country & 41.8 & 33.5 & 38.7 \\
\hline Decline of general economic system in SA & 41.8 & 36.9 & 41.8 \\
\hline Lack of resources within the SA health care system & 41.4 & 35.0 & 40.1 \\
\hline
\end{tabular}


(less experienced) and older (physically less capable) nurses who might be left to provide the bulk of the nursing services in the RSA. Losing many of these experienced nurses might also impact negatively on the teaching of student nurses, aggravating potential future shortages of nurses in the RSA.

\section{Respondents' previous and current reasons for not leaving the $R S A$}

Table 5 indicates that the most significant reason for not leaving the RSA was "family ties" (77.7\%). As more South Africans, including nurses, do continue to emigrate from the RSA, the family ties can be expected to get weaker and weaker within the RSA. Consequently health care planners should consider the possibility that more nurses will continue to emigrate in future as their family ties get weaker within the RSA. If the percentage $(46.9 \%)$ of those currently not leaving the RSA because they are still busy with studies be considered together with those relating to family ties $(77.7 \%)$, fearing the unknown (30.9\%) and lacking the courage to emigrate $(23.2 \%)$, to be reasons which could change within the foreseeable future, then health care planners in the RSA should consider the impact on the health care services should more than $50 \%$ of its employed nurses leave the country. Only $2.3 \%$ of the respondents indicated that they did not leave the RSA when they previously considered doing so, because their job applications were unsuccessful. Thus the respondents did not seem to experience major difficulties in obtaining overseas jobs.

This finding coupled with the fact that $59.8 \%$ (see Table 3 ) of the respondents indicated that they would leave the RSA, given the opportunity, should indicate the seriousness of the situation for the RSA's health care services should approximately $60 \%$ of the current actively employed nurses in the country emigrate. It might also be significant that not one respondent $(n=162)$ indicated that an unsuccessful job application was the current reason for not emigrating from the RSA. This apparently high success rate of overseas job applications might be peculiar to this research population comprising only registered nurses furthering their qualifica-

Table 5: Respondents' previous and current reasons for not leaving the RSA - given the opportunity ( $\mathrm{n}$ given for respective columns)

\begin{tabular}{|l|l|l|}
\hline Reasons for not leaving the RSA & $\begin{array}{l}\text { Previous \% } \\
(\mathrm{n}=260)\end{array}$ & $\begin{array}{l}\text { Current \% } \\
(\mathrm{n}=268)\end{array}$ \\
\hline Family ties in the RSA & 71.7 & 77.2 \\
\hline Still studying in the RSA & 39.7 & 46.9 \\
\hline Fear of the unknown & 30.9 & 25.3 \\
\hline Uncertainty & 23.2 & 17.9 \\
\hline Lacked courage to leave & 23.8 & 24.7 \\
\hline Insufficient financial resources & 19.8 & 8.6 \\
\hline I felt loyal to South Africa & 16.7 & 16.0 \\
\hline I was/am happy, content and satisfied in South Africa & 15.9 & 23.5 \\
\hline My reason changed for wanting to leave & 9.1 & \\
\hline I could not face all the emigration arrangements & 7.4 & 6.8 \\
\hline Failed to obtain the necessary travel documents & 4.8 & \\
\hline I was/am too old & 3.4 & 9.9 \\
\hline Job application was unsuccessful & 2.3 & \\
\hline No desire to leave, having traveled abroad previously & 2.3 & 5.6 \\
\hline
\end{tabular}


Table 6: Factors which would make nurses stay in the RSA ( $n$ differs for each reason as indicated in each row)

\begin{tabular}{|l|l|l|}
\hline REASON & frequency & $\%$ \\
\hline Better remuneration & 408 & 90.5 \\
\hline Better fringe benefits & 367 & 81.4 \\
\hline A more pleasant and caring work environment & 344 & 76.3 \\
\hline Improved facilities and resources within the health sector & 312 & 69.2 \\
\hline If health services in the RSA were not in such a poor state & 285 & 63.2 \\
\hline A more reasonable workload & 274 & 60.8 \\
\hline Fair and competent health services managers & 273 & 60.5 \\
\hline Healthy and improved working relationships in workplace & 257 & 57.0 \\
\hline Adequate availability of medicines in health services & 249 & 55.2 \\
\hline Less crime, rape and violence in the RSA & 231 & 51.2 \\
\hline $\begin{array}{l}\text { If there wasn't such a sense of negativity and despondency in the } \\
\text { RSA }\end{array}$ & 193 & 42.8 \\
\hline A more reasonable work tempo & 208 & 46.1 \\
\hline If there was better public schooling for my children & 111 & 24.6 \\
\hline
\end{tabular}

Table 7: What can be done by employers to keep nurses in the RSA $(n=441)$

\begin{tabular}{|l|l|}
\hline What can be done by employers to keep nurses in the RSA & $\%$ \\
\hline Better remuneration & 90.5 \\
\hline Improved fringe benefits & 82.8 \\
\hline Show appreciation for nurses' work & 81.9 \\
\hline Improved facilities and resources & 70.3 \\
\hline Appoint competent health managers & 67.3 \\
\hline Empower nurses to deal with changes in workplace & 66.0 \\
\hline Allocation of fair workload & 62.6 \\
\hline Improve interpersonal relationships in the workplace & 60.1 \\
\hline Ensure that health service managers are fair and just & 54.6 \\
\hline Adequate maintenance of discipline and order in health services & 54.0 \\
\hline Maintain a caring ethos among nurses & 45.8 \\
\hline Provide crèche facilities at work & 42.4 \\
\hline
\end{tabular}


tions through distance education courses. Their success rate for overseas job applications might be greater than those of nurses who did not obtain post-basic qualifications.

\section{Factors which would make nurses stay in the RSA}

Table 6 summarises the factors identified by the respondents $(n=452)$ which would make nurses stay in the RSA, according to their perceptions. Surprisingly, the third most important factor which would help keep nurses in the RSA (preceded by improved remuneration and fringe benefits), is a more pleasant and caring work environment, closely followed by improved health care facilities and resources.

The finding that $51.2 \%$ of the respondents would stay in the RSA if crime, rape and violence would decrease correlates with Van Rooyen's (2000:72) reports indicating that $60.0 \%$ of South African emigrants regarded crime as the major reason for leaving South Africa. In a survey among skilled South Africans 25.0\% said that improvements in safety and security would prevent them from emigrating (Mattes \& Richmond, 2000:20). A survey conducted among professional and managerial workers found the two most important rea- sons for emigration to be crime and violence (Mittner, 1999:31).

\section{What employers can do to keep nurses in the RSA}

The results are summarised in Table 7, indicating what the respondents considered could be done by their employers to keep nurses in the RSA. Better remuneration and improved fringe benefits are followed by the need that employers should show appreciation for nurses' work. This is something which could be implemented by employers at institutional level to decrease the likelihood of nurses' emigration from the RSA.

\section{What government can do to keep nurses in the RSA}

These findings indicate that improved remuneration and fringe benefits are closely followed by the need for government to appoint people in frozen posts, eliminate corruption within government and improve the safety and security situation in South Africa. These three steps, if taken by the South African Government, will not only enable more nurses to stay in the RSA, but will enhance the quality of life of all the RSA citizens.

Table 8: What can be done by government to keep nurses in the RSA ( $n=443$ )

\begin{tabular}{|l|l|}
\hline What can be done by government to keep nurses in the RSA & $\%$ \\
\hline Better remuneration & 93.0 \\
\hline Improved fringe benefits & 82.4 \\
\hline Appoint people in the many frozen posts in health services & 77.2 \\
\hline Eliminate corruption within the government & 74.7 \\
\hline Improve safety and security in South Africa & 74.7 \\
\hline $\begin{array}{l}\text { Not to introduce legislations and regulations that cannot be implemented, } \\
\text { monitored and maintained }\end{array}$ & 58.5 \\
\hline Ensure that health facilities and infrastructure are improved to its former state & 58.5 \\
\hline $\begin{array}{l}\text { Government must stop using "apartheid" as an excuse and accept } \\
\text { responsibility }\end{array}$ & 58.0 \\
\hline Get back the well qualified nurses lost through severance packages & 41.5 \\
\hline Nothing, government is doing fine & 2.7 \\
\hline
\end{tabular}


The South African Government's right to prevent nurses from finding employment elsewhere in the world

Only $32(7.1 \%)$ of the respondents indicated that the South African Government has a right to prevent nurses from emigrating to other countries, while 408 $(90.1 \%)$ denied that the Government has such a right and $13(2.9 \%)$ failed to respond to this question.

Respondents provided reasons for their "yes" responses pertaining to this issue, indicating that the South African government has no such right because:

- nurses have the same Constitutional rights as all other South African citizens to live and work where they wish to do so

- the ban on South African nurses' employment in the UK impacted negatively on the recruitment of potential student nurses; some respondents indicated that they knew of potential student nurses who pursued other careers for fear of being unable to work in foreign countries as registered nurses

- South African politicians who fought for the freedom of South Africa, cannot deny registered South African nurses their freedom of choice to work where they wish to do so.

Tlou (2001:272), during a presentation at the $22^{\text {nd }}$ Quadrennial Congress of the International Council of Nurses, supported the standpoint that banning the migration of nurses would violate nurses' human rights. Tlou (2001:272) stated: "One of the very real effects of the (HIV/AIDS) epidemic is the migration of nurses to the industrialized world .. It is a horrible brain drain and it is having adverse effects on our health care systems, but it is inevitable and one cannot end it without violating people's human rights".

\section{General comments concerning the emigr- ation of nurses from South Africa}

Respondents were requested to provide any comments about the emigration of nurses from the RSA in an open-ended question. A large number of respondents indicated that the RSA might achieve greater success by managing the emigration process rather than by trying to prohibit the emigration of nurses. Some of these comments included that:
- newly qualified nurses should be required to render one year's community service (similar to newly qualified medical practitioners) prior to becoming registered nurses, but that they should be adequately remunerated for such a service

- exchange programmes for professional nurses should be instituted among a number of different countries (similar to exchange programs for university students and academics) enabling South African nurses to maintain their permanent employment positions while they work overseas for periods ranging from 3 to 12 months while nurses from those overseas countries work in the RSA

- nurses should receive allowances for working in rural areas similar to those received by medical practitioners

- nurses should always be remunerated for overtime, and that overtime should not be subjected to its current excessive taxation making it financially less attractive

- remuneration for additional qualifications should be re-instituted

- nurses who obtain additional qualifications should be reimbursed for study fees

- more part-time posts should become available for registered nurses

- registers should be maintained of nurses working in overseas countries and support groups organised for them

- nurses who return from overseas countries should be welcomed back to the RSA and assisted to find suitable jobs; reportedly numerous agencies recruit South African nurses to work in foreign countries but there is a lack of such agencies for nurses in foreign countries seeking employment in the RSA.

\section{LIMITATIONS, CONCLUSIONS AND RECOMMENDATIONS}

The final section of this report addresses the limitations and present the conclusions and recommendations of this research project.

\section{Limitations of the research project}


The major limitations impacting negatively on the generalisability of the research results are that

- the research population was limited to nurses furthering their post-basic nursing qualifications by pursuing distance education courses, implying that this group of nurses might be better qualified and thus be more successful in finding jobs in foreign countries and in emigrating from the RSA than their colleagues

- only a postal questionnaire was used to gather data; more and different data might have been obtained if personal interviews were conducted

- the low response rate could impact negatively on the generalisability of the research results.

\section{Conclusions}

Despite the preceding limitations of the research, the respondents indicated that

- almost $60 \%$ of them would consider emigrating from the RSA should the opportunity arise

- the major factor which kept these registered nurses in the RSA was their family ties (77\%); a situation likely to change as more South Africans emigrate to foreign countries

- the overwhelming reasons for emigration relate to remuneration issues; better salaries, the ability to save money quickly for specific purposes and better fringe benefits

- besides improved remuneration and fringe benefits, employers of nurses can help to keep nurses in the RSA by showing more appreciation for nurses' work

- the South African government can help to keep nurses in the RSA by appointing persons in frozen posts and by addressing the crime and violence in the country

- almost all respondents regarded the South African Government as NOT having any right to prevent nurses from emigrating from the RSA.

\section{Recommendations}

Based on the research results, the following recommendations are proposed for addressing the emigration of nurses from the RSA:

- urgent attention should be paid to improving nurses' salaries and fringe benefits

- taxation of over time should be reduced or abolished

- factors impeding nurses' levels of job satisfaction should be identified and addressed

- nurses working in rural or high-risk areas should receive allowances similar to those received by medical practitioners

- the possibility that newly qualified nurses should render one year's community service prior to becoming registered nurses should be investigated, but they should receive adequate remuneration for such services and allowances for working in rural or high-risk areas

- the possibility of implementing registered nurse exchange programmes with other countries should be investigated and implemented

- the South African government should not place any ban on the emigration of nurses from the RSA as this impacts negatively on the recruitment of student nurses - reducing the number of nurses in the RSA even further

- frozen posts should be filled as a matter of urgency

- more part-time posts for nurses should become available

- the high median age of South African nurses should be addressed as a matter of urgency and ways and means found to encourage nurses to delay their anticipated retirement ages by 5 years or more; tax concessions, gradual retirement, part-time posts should be considered.

In order to address the phenomenon of the emigration of nurses from the RSA, further research is needed, specifically aimed at

- identifying expectations of newly qualified nurses; longitudinal studies might be valuable in identifying factors causing the emigration of nurses

- identify reasons why nurses actually emigrate from the RSA by conducting interviews prior to their departures from the RSA 
- evaluating South African nurses' experiences while working in specific foreign countries

- assisting nurses to find suitable jobs when they wish to return to the RSA

- enabling nurses aged 55 or older to postpone their retirement by five years or more

- implementing more part-time nursing jobs also for people aged 55 or older

- recruiting more student nurses

- reducing the attrition rates among students

- supporting newly qualified nurses in their first jobs

- identifying ways in which the level of job satisfaction of nurses in the RSA could be enhanced.

\section{CONCLUDING REMARKS}

The RSA needs to address the factors influencing nurses to emigrate from this country. Merely placing bans on the emigration of nurses from the RSA is unlikely to impact on this phenomenon while dire shortages of nurses exist in foreign countries, offering remuneration packages exceeding those available within the RSA up to ten times. "The prospect of medical and technological efficiency without skilled nurses to provide human care, even on a basic level, has provided a challenge of pandemic proportions. The world's attention is focusing on what can be done to alleviate the shortage of nurses and provide for the future" (Purnell et al. 2001:179).

\section{LIST OF REFERENCES}

BURNS, N \& GROVE, SK 1993: The practice for nursing research: conduct, critique and utilization. Philadelphia: WB Saunders.

CHRISTMAS, K 2002: Recruitment and retention report: invest internationally. Nursing Management, November 2002:20-21.

DEMPSEY, PA \& DEMPSEY, AD 1992: Nursing research with basic statistical applications; $3^{\text {rd }}$ edition. Boston: Jones \& Bartlett.

DENOSA 2001: Migration of nurses: Realities, threats, challenges, the way forward. Pretoria: DENOSA.

KA MZOLO, B 2001: Global migration of nurses. Nursing Update, 25(9):38.

MATTES, R \& RICHMOND, W 2000: The brain drain: What do skilled South Africans think? Africa Insight, 30(3):140-147.

MITTNER, M 1999: Why South African managers are packing for Toronto. Finance Week, 16 April: 31.

NIESWIADOMY, RM 1993: Foundations of nursing research; $2^{\text {nd }}$ edition. Norwalk: Appleton \& Lange.

NURSING UPDATE 2002-2003: December 2002/January 2003.

Volume 26, (12): (last 9 unnumbered pages with advertisements for nursing posts).

OXFORD HANDY DICTIONARY 1991: London: Chancellor Press. POLIT, DF \& HUNGLER, BP 1993: Nursing research: principles and methods; $4^{\text {th }}$ edition. Philadelphia: JB Lippincott.

PURNELL, MJ; HORNER, D; GONZALES, J \& WESTMAN, N 2001: The nursing shortage: Revisioning the future. Journal of Nursing Administration, 31(4):179-186.

TLOU, SD 2001: Nursing: a new era for action. A Virginia Henderson Memorial Lecture presented at the ICN 22 ${ }^{\text {nd }}$ Quadrennial Congress, Copenhagen. Journal of Advanced Nursing, 36(6):722-726.

VAN ROOYEN, J 2000: The new Great Trek: the story of South Africa's white exodus. Pretoria: Unisa Press.

WHO - see World Health Organization

WORLD HEALTH ORGANIZATION. 2002: Strategic directions for strengthening nursing and midwifery services. Geneva: WHO. 